\title{
NOTES AND REFLECTIONS
}

\section{NOTES ON THE DISTINCTION BETWEEN DIPLOMATIC PROTECTION AND CONSULAR PROTECTION ${ }^{1}$}

EDUARDO PIMENTEL DE FARIAS

eduardopimentelf@hotmail.com $\mathrm{PhD}$ in Law, with specialization in International Legal Sciences (Portugal).

In commonparlance, what is called diplomatic protection means, in most cases, a consular protection action. The generic notion of diplomatic protection is used to define a variety of possible forms of protection of the national abroad. This paper seeks to reflect on what lies behind the recurrent inaccuracy or error in the application of correct semantics to the type of protection of nationals abroad. Using the hypothetical deductive method, we find that in theory diplomatic and consular protection are clearly differentiated by two main axes. In practice, however, these two institutes overlap and confuse each other frequently. The solution to the problem referred to would not be based on doubt about the theory, but on the practical performance of the international actors themselves. The lack of a precise distinction between the two concepts of protection would occur more by the combination of factors resulting from the exercise of protection, than of a hesitation about theory.

Under international law, the state may exercise two types of protection for the benefit of its nationals: diplomatic protection and consular protection. Nevertheless, semantic confusion occurs in the application of these two concepts. What is called in common language diplomatic protection means, in most cases, a consular protection action. In other words, the generic notion of diplomatic protection is used to define a variety of possible forms of the national'sprotection abroad.

In theory, though, the distinction between diplomatic protection and consular protection is clear. They are differentiated by two main axes:

1) the preventive nature of consular protection as opposed to the corrective nature of diplomatic protection;

2 ) by contrast at the representation level. Therefore, while diplomatic protection is intended to correct or repair damage, consular protection is preventive in nature and is primarily intended to prevent the national from being the victim of an illicit act.

1 Note translated by Hugo Alves. 
It is clear, therefore, that in consular protection it is not necessary to exhaust internal resources, since it is a matter of "technical" assistance provided to nationals in difficulty before the commission of an illicit act ${ }^{2}$.

The other important distinction concerns the level of representation, since diplomatic protection is exercised by representatives of the interests of the injured state before the government of the offending state, while consular protection directly represents the interests of the individual in the face of the central organs of the host state. This means that in consular protection there is no political representation of the state of nationality. Such protection is initially aimed at protecting the rights of the individual and therefore requires his or her consent. On the other hand, the disinterest of the individual or even his or herexpress opposition to the demand, does not prevent the exercise of diplomatic protection since it is an action of interest to his or herstate ofnationality ${ }^{3}$.

In a synthetic way, CAFLISCH clarifies that diplomatic protection is a formal intervention that is based on law and is intended for the execution of international responsibility. And that consular protection consists of assistance provided by consular posts abroad to nationals in distress. For them, they are two different mechanisms, even when consular protection action leads to the exercise of diplomatic protection. This happens quite often since consular protection is revealed as a simpler and less formal means of state action ${ }^{4}$.

Indeed, diplomatic protection is rarer than consular protection. The violation must be exceptionally serious for the state to agree to turn it into an action of international responsibility. To this extent, the fact that generates the action of diplomatic protection, unlike consular protection, must have a dimension or an international interest of its own, capable of motivating the will to intervene of the state of nationality. Yet, this motivation depends not only on the legal order, but also on political opportunity. After all, in diplomatic protection the state exercises a right considered discretionary ${ }^{5}$.

Nonetheless, despite the clear distinction between diplomatic protection and consular protection, in practice these two institutions overlap and confuse each other frequently. In the LaGrand case, for example, the United States of America tried to convince the International Court of Justice (ICJ)that Germany was confusing consular protection with diplomatic protection. In fact, the basis of the case was the exercise of consular protection whereas the mechanism used to trigger the court is that of diplomatic protection. The IC], however, accepted the complaint as an exercise of diplomatic protection and considered that both Germany and its nationals were harmed by the violation of the right of consular protection. On the other hand, in the Avena case the court decided otherwise and ruled that the injury to Article 36 of the Vienna Convention

2 Cf. Article 55 of the Vienna Convention on Consular Relations of 1963; SHAW, Malcom N., International Law,Op. cit., p.688; TAXIL, Bérangère, L'Individu, entre Ordre Interne et Ordre International: Recherches sur la Personnalité Juridique Internationale., p.493; DUGARD, John,Septième Rapport sur la Protection Diplomatique, pp.7-8, 11.

3 Cf. Paragraph 1 of Article 36 of the Vienna Convention on Consular Relations of 1963; TAXIL, Bérangère. L'Individu, entre Ordre Interne et Ordre International: Recherches sur la Personnalité Juridique Internationale., Op. cit.,p.493; DUGARD, John,Septième Rapport sur la Protection Diplomatique, op.cit., pp.7-8 and 11 .

4 CAFLISCH, Lucius, La Pratique Suisse de la Protection Diplomatique, p.77.

5 PANCRACIO, Jean-Paul et al.,Communication sur la Protection Consulaire et Diplomatique: Concurrence ou Complémentarité?, p.80. See also the trial of the Case Concerning Barcelona Traction, Light and PowerCompany, Limited, Judgment, I.C.J. Reports 1970, par.79. 
on Consular Relations caused a direct injury to Mexico. For the ICJ, it was no longer necessary to deal with the Mexican complaint concerning the violation of the right of consular protection under the different angle of diplomatic protection ${ }^{6}$.

Another practical example of confusion between the concepts of diplomatic protection and consular protection stems from the Article 23 of the Treaty on the Functioning of the European Union (TFEU). Such article provides that all Union citizens are protected on foreign territory by the diplomatic and consular authorities of any member state. The European norm, however, ignores the fundamental differences that exist between these two mechanisms, particularly regarding the conditions for the exercise of diplomatic protection?

The confusion is such that a significant part of the doctrine argues that the Article 23 of the TFEU illustrates a case of consular protection and not diplomatic protection. For them, only the amiable nature of consular protection would be able to justify the concept of cooperation proposed in the TFEU. Moreover, the notion of EU citizenship would also not satisfy the nationalityrequirement in diplomatic protection, because it is mediated by the nationality of one of the EU members states ${ }^{8}$.

Between diplomatic protection and consular protection, we still find one last identification problem related to international practice. Thelatter has largely shown that states react with a dual purpose: a restorative one, with the aim of constituting the satisfaction of injury, and another of a preventive nature, aiming to guarantee the right to life and property of nationals abroad. CONDORELLI thus developed the concept of preventive diplomatic protection. He believes that the state's preventive actions against the threat or the risk of violation of the international norm should also be part of a wider notion of diplomatic protection. This notion would therefore include the traditional concept of diplomatic protection, which he callsstrictosensudiplomatic protectionandwhich represents the reaction of the injured state against an illicit fact already perpetrated with the concept of consular protection, which he prefers to call preventive diplomatic protection, but which is the state's reaction against risk ${ }^{9}$.

This sense of the wider interpretation of diplomatic protection was not, however, welcomed by the 2006 International Law Commissiondraft Article 1 on diplomatic protection. Its comment clarifies that although it is not necessarily contentious, diplomatic protection is an action after the illicit fact. That is, in TAXIL'S OPINION, a

6 Case of LaGrand (Allemagne c. Etats-Unis d'Amérique), CIJ Recueil 2001, par. 77; Avena et autres Ressortissants Mexicains (Mexique c. Etats- Unis d'Amerique),CIJ Recueil 2004, par.40.Seealso DEENRACSMÁNY, Zsuzanna,Diplomatic Protection and the LaGrand Case,p.93; ROBERT, Eric,La Protection Consulaire des Nationaux en Péril? Les Ordennances en Indication de Mesures Conservatoires redues par la Cour Internationale de Justice dans les Affaires Bread (Paraguay c. États-Unis) et LaGrand (Allemagne c. États-Unis), pp.413 etss; DUPUY, Pierre-Marie,La Protection Consulaire sous les Feux de la Jurisprudence Internationale, p.39 et ss.

7 Cf. Article 23 of TFEU. See commentary by Moura Ramos on the topic in PORTO, Manuel Lopes; ANASTÁCIO, Gonçalo, Treaty of Lisbon-Annotated and Commented. pp.262-263.

8 Cf. STEIN, Torsten, Interim Report on "Diplomatic Protection Under the European Union Treaty", pp.3637; PANCRACIO, Jean-Paul et al., Communication sur la Protection Consulaire et Diplomatique: Concurrence or Complémentarité?, op. cit., p.83.

9 CONDORELLI, Luigi, La Protection Diplomatique et I'Evolution de son Domaine d'Application Actuelle, pp.7-8. 
logical attitude because the draft articles on diplomatic protection must be understood in strong connection with the text on international responsibility of the state ${ }^{10}$.

For the ILC, therefore, diplomatic protection consists in the invocation by a state, through diplomatic action or other means of peaceful settlement, of the international responsibility of another state in the face of injury caused by an internationally wrongful act committed against a subject of nationality of the first state ${ }^{11}$.

The draft articles of the ILC thus preservethe distinction between diplomatic action and legal action as means of exercising diplomatic protection. The latter, moreover, is part of the expression "other means of peaceful settlement", which covers all lawful forms of dispute disposition, ranging from negotiation, mediation and conciliation to arbitration and judicial arrangement. On the other hand, the term "diplomatic action" extends to all lawful procedures used by states to inform each other of their views and concerns, including protesting and requesting investigation of the dispute ${ }^{12}$.

International caselaw goes in that sense and allows diplomatic protection to be admissible only if based on the invocation of the injured interest. Even in the paradigmatic Barcelona Traction case, the IC] clearly stated that there is only international responsibility if the law has been harmed and not only affected ${ }^{13}$.

The Vienna Convention on Diplomatic Relations of 1961 still provides that diplomatic missions have legal competence for the exercise of consular protection. In accordance with paragraph 2 of itsarticle 3, no provision of this Convention may be construed as preventing the exercise of consular functions by the diplomatic mission ${ }^{14}$.

Consular agents may also intervene to support the central authorities of the sending state or the diplomatic mission itself in verifying facts on the ground and even in resolving a case of diplomatic protection. Nevertheless, diplomatic action itself needs to be maintained at the level of the central services of the sending state, as it reveals a legal dimension particularly demarcated by a dual interest. It is undeniable that all diplomatic action meets the interests of the individual injured party, but also the interest of his or herstate of nationality as a subject of international law.

It is worth mentioning, however, that consular protection is still unfolding in the figure of consular assistance. According to Article 5(a) and (e) of the Vienna Convention on Consular Relations of 1963, protection and assistance are two different consular functions. Whereas in consular protection there is an activity provided by the consular office on a regular and customary basis, consular assistance is provided on an occasionalbasis, with the objective of renderingassistance to individuals or legal entities of the sending state.

For all this, consular protection activity means the following types of interventions: support for an imprisoned national, action against discriminatory treatment of nationals in the host state, technical support in a judicial procedure in which the national is a victim or perpetrator, as well as the protection of the property interests of the national

10 TAXIL, Bérangère, L'Individu, entre Ordre Interne et Ordre International: Recherches sur la Personnalité Juridique Internationale, Op.cit., p.496.

11 Cf. Article 1 of the 2006 ILCDraft Articles on Diplomatic Protection.

12 Projet $d^{\prime}$ Articles sur la Protection Diplomatique et Commentaires y Relatifs (2006), p. 27. See also DUGARD, John, Septième Rapport sur la Protection Diplomatique, op.cit. p.7.

13 Cf. Barcelona Traction, Light and Power Company, Limited,arrêt, C.I.J. Recueil 1970. par.46.

14 Cf. Article 3 of the Vienna Convention on Diplomatic Relations, 1961. 
threatened by a nationaldecision, expropriation, or requisition. On the other hand, consular assistance is the aid provided to indigent or hospitalized nationals, logistical and material assistance in case of repatriation or evacuation, as well as support in the repatriation of sick citizens and in the transfer of remains, among other hypotheses. Whereas consular assistance only requires a situation of disgrace or need of the national, consular protection is motivated by the possibility of violation of domestic or international law ${ }^{15}$.

Having clarified the distinction between diplomatic and consular protection in theory, it remains to be understood why such confusion persists in international practice. What would be behind the recurrent inaccuracy or error in the application of correct semantics to the type of protection of the national abroad, if the theory on the subject is clear and right?

The solution to the problem, though, would not be based on uncertainty or doubt about the theory, but in the practical performance of the very international actors in charge of that protection themselves. We believe that the lack of a precise distinction between the two concepts of protection is due more toa combination of factors arising from the exercise of protection, than to a hesitation about the theory. Among the various factors arising from the exercise of protection, we can list at least three, which we consider decisive in fostering confusion between the concepts of consular and diplomatic protection: 1) in international practice, institutional actors are often the same for consular protection action and for diplomatic protection action; 2) diplomatic and consular agents do not usually use a strict language that allows toinfallibly dissociate the two protection modalities; and 3) both diplomatic protection and consular protection are even intended to protect the rights and interests of their nationals in the territory of a foreign state.

Finally, in the same sense that we maintain that the reason for the confusion between the concepts of consular and diplomatic protection lies in the actions of the international agents themselves, we also argue that the solution to such inaccuracy will necessarily come from the practice of these same agents. They are, after all, the most interested in clarifying the current limits and possible advances that are observed in the protection of nationals abroad.

\section{References}

Avena et Autres Ressortissants Mexicains. Mexique c. Etats-Unis d'Amerique (2004), CIJ, Recueil 2004, Trial of 31.03.2004.Accessed on May 17, 2021. Available athttps://www.icj-cij.org/fr/affaire/128.

Barcelona Traction, Light and Power Company, Limited (1970). Arrêt, CIJ, Recueil 1970. Trial of 5.02.1970. Accessed on May 17, 2021. Available athttps://www.icjcij.org/public/files/case-related/50/5387.pdf

Brotóns, Antonio Remiro et al (1997),Derecho Internacional,Madrid: McGraw-Hill.

15 Cf. Article 5 of the Vienna Convention on Consular Relations of 1963; PANCRACIO, Jean-Paul et al. Communication sur la Protection Consulaire et Diplomatique: Concurrence or Complémentarité? Op. cit. p.79; BROTÓNS, Antonio Remiro et al.,Derecho International, p.500; LICERAS, Juan Soroeta. La Protección de la Persona Humana en Derecho internacional, p.26; RIDRUEJO, José Antonio Pastor,Derecho Internacional Público y Organizaciones Internacionales, p.246. 
Caflisch, Lucius (2003). La Pratique Suisse de la Protection Diplomatique, In JeanFrançois Flauss (dir.), La Protection Diplomatique-Mutations Contemporaines et Pratiques Nationales, pp. 73-86 Bruxelles: Bruylant.

Condorelli, Luigi (2003). «La Protection Diplomatique et I'Evolution de son Domaine d'Application Actuelle», inRivista de DirittoInternazionale, 86 (1), 5-26.

Convenção de Viena sobre Relações Consulares (1963),Decreto-Lei n. 183/72. Diário da República, I Série, no 74, de 27.03.1968.

Convenção de Viena sobre Relações Diplomáticas (1961),Decreto-Lei n.0 48295.Diário da República, I Série, no 74, de 27.03.1968.

Deen-Racsmány, Zsuzanne (March 2002), Diplomatic Protection and the La Grand Case, in Leiden Journal of International Law, Cambridge: Cambridge University Press, 15 (1), 87-103.

Dugard, John R. (2006), Septième rapport sur la protection diplomatique. Doc. A/CN.4/567. Accessed on May 17, 2021. Available at https://undocs.org/en/A/CN.4/567.

Dupuy, Pierre-Marie (2006), La Protection Consulaire sous les Feux de la Jurisprudence Internationale, inJournée d'étude de Lyon-La Protection Consulaire. Paris: Pedone.

LaGrand (Allemagne c. Etats-Unis d'Amérique), CIJ, Recueil 2001. Trial of 27.06.2001,Accessed on May 17,2021. Available at https://www.icjcij.org/public/files/case-related/104/104-20010627-JUD-01-00-FR.pdf.

Liceras, Juan Soroeta (2000), La Protección de la Persona Humana en Derecho Internacional, in Carlos Fernández de Casadavente (Coord.),Derecho Internacional de los Derechos Humanos (pp. 19-48). Madrid: Dilex, .

Pancracio, Jean-Paul, Haquani, Zalmaï, Aydan, Ozer (2006),Communication sur la Protection Consulaire et Diplomatique: Concurrence ou Complémentarité? In Journée d'étude de Lyon-La Protection Consulaire, Paris: Pedone.

Porto, Manuel Lopes, Anastácio, Gonçalo (Coord.) (2012), Tratado de Lisboa- Anotado e Comentado. Coimbra: Almedina.

Projet d'Articles sur la Protection Diplomatique et Commentaires y Relatifs(2006). Doc. A/61/10.Accessed on May 17,2021. Available at https://undocs.org/en/A/61/10.

Ridruejo, José Antonio Pastor (1999), Curso de Derecho Internacional Público y Organizaciones Internacionales (7th ed.), Madrid: Tecnos.

Robert, Eric (1988). La Protection Consulaire des Nationaux en Péril? Les Ordennances en Indication de Mesures Conservatoires Redues par la Cour Internationale de Justice dans les Affaires Bread (Paraguay c. États-Unis) et LaGrand (Allemagne c. États-Unis), Revue Belge de Droit International, 31 (2), 414-449.

Shaw, M.N (2003), International Law (5th.ed), Cambridge: Cambridge University Press.

Stein, Torsten. Interim report on 'diplomatic protection under the European Union treaty. In Report of the Seventieth Conference held in New Delhi, 2-6 April 2002, London: International Law Association. 
Taxil, Bérangère. L'Individu, entre Ordre Interne et Ordre International: Recherches sur la Personnalité Juridique Internationale (2005). (PhD thesis supervised by Brigitte Stern) University of Paris I Panthéon-Sorbonne. Lille: Atelier national de reproduction des thèses.

\section{How to cite this note}

Farias, Eduardo Pimentel de (2021). Notes on the distinction between diplomatic protection and consular protection. Notes and Reflexions. Janus.net, e-journal of international relations. Vol12, No. 2, November 2021-April 2022. Consulted [online] at date of last visit, https://doi.org/10.26619/1647-7251.12.2.01

(c) (i) 